\title{
ANTIBACTERIAL EFFICACY OF SILVER OR ARSENIC DOPED POLYMER COMPOSITES AGAINST SEVERAL KINDS OF BACTERIA
}

\author{
Witold Brostow ${ }^{1} \bowtie$, Marina Gahutishvili1,2, Anthony W. Wren ${ }^{3}$, Timothy J. Keenan ${ }^{3}$, \\ Chokchai Yatongchai ${ }^{3}$, Nathalie Hnatchuk ${ }^{1}$, Vijay Singh ${ }^{4}$
}

https://doi.org/10.23939/chcht16.01.042

\begin{abstract}
Structure and several properties of $\mathrm{AgNO}_{3}$ and $\mathrm{As}_{2} \mathrm{O}_{3}$ doped polymer composites have been investigated, including their antibacterial activity against E. coli, S. aureus, C. albicans and S. epidermidis. New silver or arsenic doped polymer composites have been characterized by an X-ray diffraction (XRD), a scanning electron microscopy combined with an energy dispersive $\mathrm{X}$-ray spectroscopy (SEM/EDS) and ion release studies. The antibacterial evaluation of each of the composite samples was conducted using $S$. aureus in the liquid broth culture, with 10, 20 and $30 \%$ of liquid extract added to the bacterial culture. Control $S$. aureus stocks were used for comparison at each time period and were recorded at $100 \%$ at each time period. For samples with the PLA plasticizer the bacterial viability was significantly reduced for each composition containing $\mathrm{Ag} / \mathrm{As}$ and was similar for each dosage concentration.
\end{abstract}

Keywords: arsenic composites, silver composites, polymer composites, antibacterial behavior.

\section{Introduction}

Currently there exists a clinical need for materials and surfaces that inhibit the growth and proliferation of pathogenic microbes. Studies have been conducted to incorporate organic compounds such as antibiotics into medical materials and surgical contact surfaces to eliminate opportunistic pathogens such as $S$. aureus. However, overuse of these compounds has resulted in the generation of antibiotic resistant organisms such as

\footnotetext{
${ }^{1}$ Laboratory of Advanced Polymers \& Optimized Materials (LAPOM), Department of Materials Science and Engineering and Department of Physics, University of North Texas, 3940 North Elm Street, Denton, TX 76207, USA

${ }^{2}$ Department of Chemistry, Ivane Javakhishvili University, 3 Ilya Chavchavadze Ave., 0179 Tbilisi, Georgia

${ }^{3}$ Inamori School of Engineering, Alfred University, Alfred, NY, USA

4 Department of Biological Sciences, University of North Texas, Denton. TX, USA.

凶kbrostow@gmail.com

(C) Brostow, W.; Gahutishvili, M.; Wren, A.W.; Keenan, T.J.; Yatongchai, C.; Hnatchuk, N.; Singh, V., 2022
}

methicillin resistant $S$. aureus (MRSA) and vancomycin resistant $S$. aureus (VRSA). Currently, post-surgical infection rates of orthopedic implants range from 0.3 to $8.8 \%$. These infections are reported to be caused by a surgical contamination of wounds, hematogenous spread, reoccurrence related to sepsis from a previously infected joint, or spread of infection from a preexisting source. Clearly it is desirable to impart medical materials and contact surfaces with non-antibiotic containing antimicrobial properties which can eliminate opportunistic microbes upon contact. A potential mechanism of achieving this is through the addition of metallic cations such as silver $\left(\mathrm{Ag}^{+}\right)$, copper $\left(\mathrm{Cu}^{2+}\right)$ and zinc $\left(\mathrm{Zn}^{2+}\right)-$ in addition to metallic nanoparticles. It is widely known that $\mathrm{Ag}^{+}$is an effective antibacterial agent as it has a low cytotoxicity in wound dressings and is highly bactericidal - the primary reason for its inclusion in antimicrobial materials and coatings ${ }^{1,2}$.

Largely the development of antimicrobial polymers has been based on the dispersion of metallic nanoparticles in a medium within a polymeric matrix. In order to achieve the desired properties, $\mathrm{Ag}^{+}$nanoparticles typically have to be smaller than $50 \mathrm{~nm}$ in diameter, otherwise they exhibit similar properties to bulk particles ${ }^{3}$. Polymeric matrix without metallic nanoparticles is investigated for other applications such as improving the mechanical properties. Gold $(\mathrm{Au})$ nanoparticles have previously been created by a laser ablation and placed in polystyrene (PS) matrices ${ }^{4}$. PS is characterized by a high wear, but the addition of $\mathrm{Au}$ nanoparticles with concentrations below $1 \mathrm{wt} \%$ results in reducing friction and lowering wear rates ${ }^{5}$. Moreover, values of brittleness of PS are much higher that of other engineering polymers ${ }^{5,6}$. Earlier some of us reported procedures for the separation of natural trivalent oxides of arsenic $\left(\mathrm{As}_{2} \mathrm{O}_{3}\right)$ and antimony $\left(\mathrm{Sb}_{2} \mathrm{O}_{3}\right){ }^{7}$, in addition to the synthesis and processing of adamantanecontaining hydrazide-hydrazones with Co and Ni. Such materials have been used to prevent biocorrosion of cultural heritage and museum exhibits ${ }^{8}$.

This paper deals with the antibacterial effects of $\mathrm{Ag}_{2} \mathrm{O}$ and $\mathrm{As}_{2} \mathrm{O}_{3}$, the addition of these oxides to polymeric networks, investigation of resulting structures and their 
solubility. One of the primary reasons to conduct the present work is the easy availability of $\mathrm{As}_{2} \mathrm{O}_{3}$ in the Republic of Georgia ${ }^{9,10}$ while these oxides are known to exhibit also anti-cancerous properties ${ }^{11-13}$. The potential benefit of arsenic as an antibacterial agent was recognized when $\mathrm{As}_{2} \mathrm{O}_{3}$ was added in small concentrations to poly(vinyl chloride) ${ }^{14}$. Sufficient antibacterial activity has been achieved when tested in E. coli and P. syringae media ${ }^{14}$. We explore the antibacterial properties of $\mathrm{As}_{2} \mathrm{O}_{3}$ when added to a widely used polymer, namely poly(vinyl chloride) (PVC), and comparing it to a known antimicrobial agent, $\mathrm{Ag}_{2} \mathrm{O}$.

\section{Experimental}

\subsection{Material Synthesis}

To create samples of silver and arsenic doped polymer composites, the following materials were used: $\mathrm{PVC}, \mathrm{Zn} / \mathrm{Ca}$ salt, arsenic(III) oxide, silver nitrate, and also bio-based plasticizers: Hexamoll DINCH (Hex-C), LPLAS HT3 (Pla-c) and ECOLOBRIUM (Eco-C).

The PVC grade called SE1300N was provided by Shintech Inc, Houston, TX, USA, and was used as the main polymer matrix. It contains vinyl chloride monomer up to $10 \mathrm{ppm}$ by weight and was used without further purification. All materials are commercially available.

For all samples, the amounts of $\mathrm{PVC}, \mathrm{Zn} / \mathrm{Ca}$ stabilizer, and plasticizer were kept constant at 10, 0.1 and $0.25 \mathrm{~g}$, respectively. Antimicrobial functional agents $\mathrm{As}_{2} \mathrm{O}_{3}$ and $\mathrm{AgNO}_{3}$ were incorporated into polymeric matrices (Table 1).

Since three different plasticizers named above were used to prepare three different series of samples, we thus created nine samples.

PVC was mixed with $\mathrm{Zn} / \mathrm{Ca}$ stabilized with a strong agitation until a homogeneous dispersion was obtained; a plasticizer was added to this mixture preheated up to $333 \mathrm{~K}$ and agitated before use. The purpose of this step is to homogenize the plasticizer as much as possible in case any crystallization, aggregation or settling occurred at room temperature during storage. The plasticizer was then slowly added and mixed until full plasticizer absorption was achieved (this varies with the plasticizer). $10 \mathrm{mM} \quad \mathrm{AgNO}_{3}$ solution was initially prepared. Arsenic(III) oxide powder was dissolved in water. Finally antibacterial agent arsenic(III) oxide or $10 \mathrm{mM}$ solution of silver nitrate, or both together, were added slowly with the strong agitation. Since our three plasticizers were used to prepare three different series of samples, we created overall twelve samples. Thus:

- control samples HEX-C, PLA-C and ECO-C are free from an antibacterial agent;

- HEX-1, PLA-1 and ECO-1 contain arsenic (III) oxide;

- HEX-2, PLA-2 and ECO-2 contain silver ions;

- HEX-3, PLA-3 and ECO-3 contain both silver and arsenic ones.

All samples were processed in a DAKE compression molding machine, Model 44-250, Grand Haven, MI, USA, at $423 \mathrm{~K}$ and at the compressive pressure of $1.33 \mathrm{kPa}$. Samples of each formulation were prepared as discs $2.0 \mathrm{~cm}$ in diameter and $0.5 \mathrm{~cm}$ in thickness for antibacterial and structural analysis.

\subsection{X-Ray Diffraction}

Diffraction patterns were collected using a Siemens D5000 X-ray Diffraction Unit (Bruker AXS Inc., Madison, WI, USA). Polymer plate samples were loaded into standard stainless steel sample holders. A voltage generator of $40 \mathrm{kV}$ and a tube current of $30 \mathrm{~mA}$ were employed. Diffractograms were collected in the range of $10^{\circ}<2 \theta<70^{\circ}$, at a scan step size $0.02^{\circ}$ and a step time of $10 \mathrm{~s}$. Any crystalline phases present were identified using JCPDS (Joint Committee for Powder Diffraction Studies) standard diffraction patterns.

Table 1. Compositions of Ag/As doped polymer composites

\begin{tabular}{|c|c|c|c|c|c|}
\hline Sample & PVC, $\mathrm{g}$ & $\mathrm{Zn} / \mathrm{Ca}$ stabilizer, $\mathrm{g}$ & Plasticizer, $\mathrm{g}$ & $10 \mathrm{mM} \mathrm{AgNO} \mathrm{HL}_{3}, \mathrm{~mL}$ & $\mathrm{As}_{2} \mathrm{O}_{3}, \mathrm{~g}$ \\
\hline HEX-C & 10 & 0.1 & 0.25 Hexamoll DINCH & - & - \\
\hline HEX-1 & 10 & 0.1 & 0.25 Hexamoll DINCH & - & 0.2 \\
\hline HEX-2 & 10 & 0.1 & 0.25 Hexamoll DINCH & 2.5 & - \\
\hline HEX-3 & 10 & 0.1 & 0.25 Hexamoll DINCH & 1.5 & -2 \\
\hline PLA-C & 10 & 0.1 & 0.25 LPLAS HT3 & - & - \\
\hline PLA-1 & 10 & 0.1 & 0.25 LPLAS HT3 & - & - \\
\hline PLA-2 & 10 & 0.1 & 0.25 LPLAS HT3 & 2.5 & 0.2 \\
\hline PLA-3 & 10 & 0.1 & 0.25 LPLAS HT3 & 1.5 & - \\
\hline ECO-C & 10 & 0.1 & 0.25 ECOLOBRIUM & - & - \\
\hline ECO-1 & 10 & 0.1 & 0.25 ECOLOBRIUM & - & - \\
\hline ECO-2 & 10 & 0.1 & 0.25 ECOLOBRIUM & 2.5 & 0.2 \\
\hline ECO-3 & 10 & 0.1 & 0.25 ECOLOBRIUM & 1.5 & \\
\hline
\end{tabular}




\subsection{Scanning Electron Microscopy and Energy Dispersive X-Ray Analysis (SEM/EDX)}

A Quanta 200F Environmental Scanning Electron Microscope (SEM) was used to obtain images of the samples under a vacuum of $0.12 \mathrm{kPa}$. The electron beam was used at an accelerating voltage of $20 \mathrm{kV}$ and a spot size of 4.0. Energy dispersive X-ray spectroscopy (EDS) was carried out using FEI EDAX system equipped with a silicon-drift detector.

\subsection{Inductively Coupled Plasma - Atomic Emission Spectroscopy (ICP- AES)}

Each sample $(5 \mathrm{~mm} \times 5 \mathrm{~mm} \times 0.5 \mathrm{~mm}) \quad$ was immersed in a sterile de-ionized $\mathrm{H}_{2} \mathrm{O}$ for 30 days and rotated on an oscillating platform at $310 \mathrm{~K}$. The ion release profile of each glass was measured using the Inductively Coupled Plasma - Atomic Emission Spectroscopy (ICP-AES) on a Perkin-Elmer Optima 5300UV (Perkin Elmer, Waltham, MA, USA). ICP-AES calibration standards for As and Ag ions were prepared from a stock solution on a gravimetric basis. Three target calibration standards were prepared for each ion and deionized water was used as a control.

\subsection{Antibacterial Analysis of Composites using $S$. aureus}

The antibacterial properties of the Ag and Asdoped samples were tested in comparison to the control samples free of $\mathrm{Ag}$ or As with UAMS-1 S. aureus (tripticase soy agar and broth). Prior to testing, each microbe was initially grown aerobically in a liquid broth at $310 \mathrm{~K}$ for $24 \mathrm{~h}$ and spread plated on agar plates with a sterile swab dipped in a $1 / 50$ dilution of the appropriate 24-hour culture of bacteria. One colony of the appropriate 24-hour plated culture of bacteria was grown aerobically in the liquid broth at $310 \mathrm{~K}$ for $24 \mathrm{~h}$. The $1 / 50$ dilution of the bacteria was performed and $150 \mu \mathrm{L}$ was used to inoculate the culture for testing; $1 \mathrm{~mL}$ bacterial broth was used per sample. Samples were placed in 24-well plates and these plates incubated for $24 \mathrm{~h}$ at $310 \mathrm{~K}$. After incubation, $100 \mu \mathrm{L}$ of broth was taken from each well and pipetted into a 96-well plate $(n=3 /$ sample, total $n=9)$. To determine bacteria concentration within the broth, the extracts absorbance was analyzed with a Bio-Tek $\mu$ Quant plate reader at a wavelength of $490 \mathrm{~nm}$. Samples were initially tested at concentrations of 10,20 and $30 \%$ to determine the effect of aliquot concentration. Further testing was conducted using $10 \%$ aliquot concentration so that the viability of $S$. aureus in the liquid broth was evaluated at $6,12,24$ and $48 \mathrm{~h}(n=3)$ with the Bio-Tek $\mu$ Quant plate reader where total aliquots of $100 \mu \mathrm{L}$ were used at each of the respective time intervals.

\section{Results and Discussion}

Testing results. Initially characterization of the materials was conducted to determine differences in the structure, morphology and solubility of the processed composites. The characterization included X-ray diffraction to determine if the addition of $\mathrm{Ag}_{2} \mathrm{O}$ or $\mathrm{As}_{2} \mathrm{O}_{3}$ affected the structures. The results are presented in Figs. 1,2 and 3 for the HEX, PLA and ECO series of composites, respectively. HEX-C did not contain any $\mathrm{Ag}_{2} \mathrm{O}$ or $\mathrm{As}_{2} \mathrm{O}_{3}$ as expected, while organic components of the polymer phase were evident: $\mathrm{C}_{12} \mathrm{H}_{7} \mathrm{NO}_{2}$ and $\mathrm{C}_{2} \mathrm{H}_{3} \mathrm{Cl}$. Amorphous humps are present within the $15-30^{\circ} 2$ theta range. HEX-1 and HEX-3 are found to contain crystalline peaks indicative of $\mathrm{As}_{2} \mathrm{O}_{3}$ while the incorporation of $\mathrm{Ag}_{2} \mathrm{O}$ did not induce any crystallinity in HEX-2 and HEX3. X-ray diffraction patterns of PLA (Fig. 2) and ECO (Fig. 3) follow a similar trend to HEX where crystalline $\mathrm{As}_{2} \mathrm{O}_{3}$ was present in PLA-1, PLA-3, ECO-1 and ECO-3 while crystalline $\mathrm{Ag}_{2} \mathrm{O}$ was not evident in any of the samples tested.

Scanning electron microscopy (SEM) and energy dispersive X-ray (EDX) analysis were used to further image the composite samples to verify processing consistency and determine the elemental composition. Representative SEM images are presented in Fig. 4 for ECO, PLA and HEX samples. ECO-2 and 3 samples are presented in Fig. 4a and 4b. The higher contrast in ECO-2 is likely a result of the higher $\mathrm{Ag}_{2} \mathrm{O}$ concentration in this composite. ECO-3 shows a higher degree of adhesion between the constituents when compared to ECO-2. PLA1 and PLA-2 are presented in Fig. $4 \mathrm{c}$ and 4d; the higher contrast in PLA-2 than in PLA-1 is likely due to the presence of $\mathrm{Ag}_{2} \mathrm{O}$. HEX-1 and HEX-3 are presented in Fig. $4 \mathrm{e}$ and $4 \mathrm{f}$. The scattered patches seen for ECO-3, PLA-1, HEX-1 and HEX-3 are likely clusters of $\mathrm{As}_{2} \mathrm{O}_{3}$ since these clusters are only evident in the $\mathrm{As}_{2} \mathrm{O}_{3}$ containing composites. The corresponding EDX is presented in Fig. 5 for ECO, PLA and HEX. EDX of the ECO series of composites is shown in Fig. 5a. Ag and As are absent in ECO-C - as expected. As is present in ECO1 and ECO-3 and Ag is present in ECO-2 but absent in ECO-3. Possibly the concentrations of Ag are below the detection limit of EDX. Also, $\mathrm{Zn}$ is observed in EDX for each sample since it is incorporated during processing in a plasticizer. Both the PLA and the HEX series of composites (Fig. 5b and 5c) show a similar trend while Ag and As are absent in PLA/HEX-C, As is present in 
PLA/HEX-1 and PLA/HEX-3 and Ag is present in PLA/HEX-2 and PLA/HEX-3, as expected.

The solubility of each of the composite materials was evaluated using an Inductively Coupled Plasma Optical Emission Spectroscopy (ICP-OES), where Ag and As levels were recorded specifically after $24 \mathrm{~h}$ incubation in sterile DI water. The results of the ICP-OES study are presented in Table 2. For each of the control materials tested, i.e. HEX-C, PLA-C and ECO-C) no Ag or As release was found - again as expected. As release was recorded for HEX-1 (13.6 mg/L), PLA-1 $(8.6 \mathrm{mg} / \mathrm{L})$ and ECO-1 (19.3 mg/L). Ag release was found to be $<1 \mathrm{mg} / \mathrm{L}$ for all composite samples tested. In the composite series containing $\mathrm{Ag}$ and $\mathrm{As}$, As release was found to be slightly higher than in the As alone series. As level for HEX-3 was $12.2 \mathrm{mg} / \mathrm{L}$, for PLA-3 $11.2 \mathrm{mg} / \mathrm{L}$, and for ECO-3 $21.5 \mathrm{mg} / \mathrm{L}$.

Antibacterial evaluation of each of the composite samples was conducted using $S$. aureus in the liquid broth culture, with 10, 20 and $30 \%$ of liquid extract added to the bacterial culture. Control $S$. aureus stocks were used for comparison at each time period and were recorded at $100 \%$ at each time period. Regarding PLA, the results are presented in Fig. 6a; the bacterial viability was significantly reduced for each composition containing $\mathrm{Ag} / \mathrm{As}$ and was similar for each dosage concentration. For $10 \%$ addition, PLA-1, PLA-2, PLA-3 were found to be 58,45 and $57 \%$, respectively. Similarly for the $20 \%$ dosage, bacterial viability was evident at 44,36 and $56 \%$ for PLA-1, PLA-2 and PLA-3, respectively. The 30\% dosage exhibited a slightly higher bacterial viability at 47 , 54 and $62 \%$ for each of the PLA samples, respectively. The Ag/As free PLA composition (PLA-C) did not exhibit any bactericidal properties. The HEX samples did not show a significant reduction at $10 \%$ dosage; the results are presented in Fig. 6 b. The bacterial viability was found to be 93,95 and $97 \%$ for HEX-1, HEX-2 and HEX-3, respectively, at $10 \%$ dosage. At $20 \%$ dosage, the viability improved to 51, 72 and $59 \%$ for the HEX series and at $30 \%$ - the bacterial viability was at 69,74 and $56 \%$ for HEX-1, HEX-2 and HEX-3, respectively. The HEX-C samples did not present any antibacterial properties under each condition. Results for the ECO samples are presented in Fig. 6c; bacterial viabilities are 75, 99 and $88 \%$ for ECO-1, ECO-2 and ECO-3, respectively, at a dosage of $10 \%$. At $20 \%$ the bacterial cell viability was reduced to 63,59 and $49 \%$ for each composition respectively, while the $30 \%$ dosage increased the bacterial viability slightly to 74, 77 and $73 \%$ for ECO-1, ECO-2 and ECO-3. The $\mathrm{Ag} / \mathrm{As} \mathrm{ECO}-\mathrm{C}$ free sample does not show any bactericidal effect under any condition.

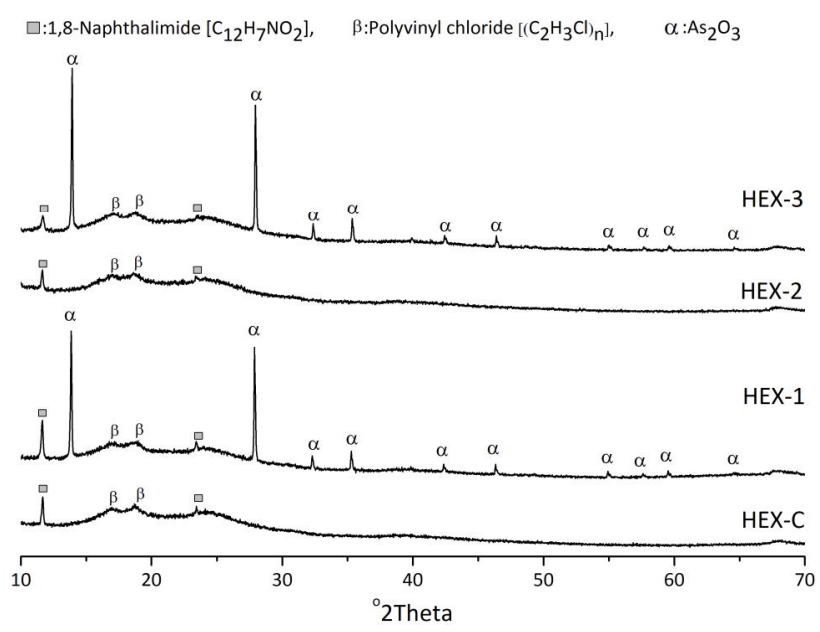

Fig. 1. X-ray diffraction of HEX series of Ag and As doped polymers

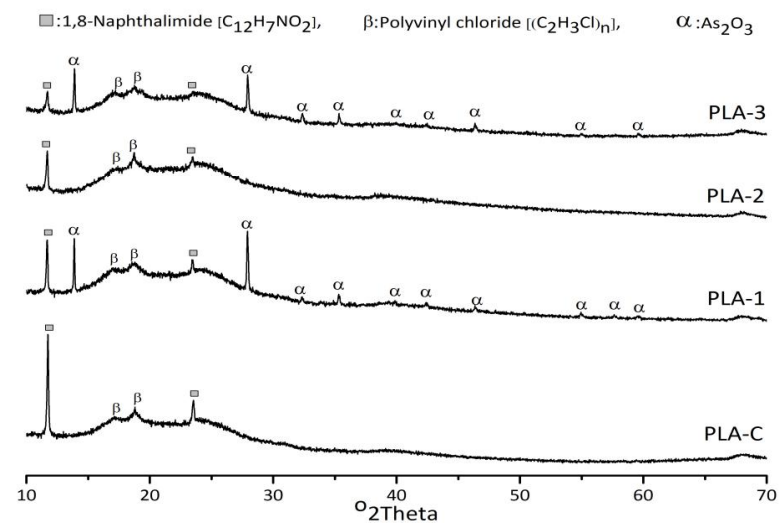

Fig. 2. X-ray diffraction of PLA series of Ag and As doped polymers

$\square: 1,8-$ Naphthalimide $\left[\mathrm{C}_{12} \mathrm{H}_{7} \mathrm{NO}_{2}\right], \quad \beta$ :Polyvinyl chloride $\left[\left(\mathrm{C}_{2} \mathrm{H}_{3} \mathrm{Cl}\right)_{n}\right], \quad \alpha: \mathrm{As}_{2} \mathrm{O}_{3}$
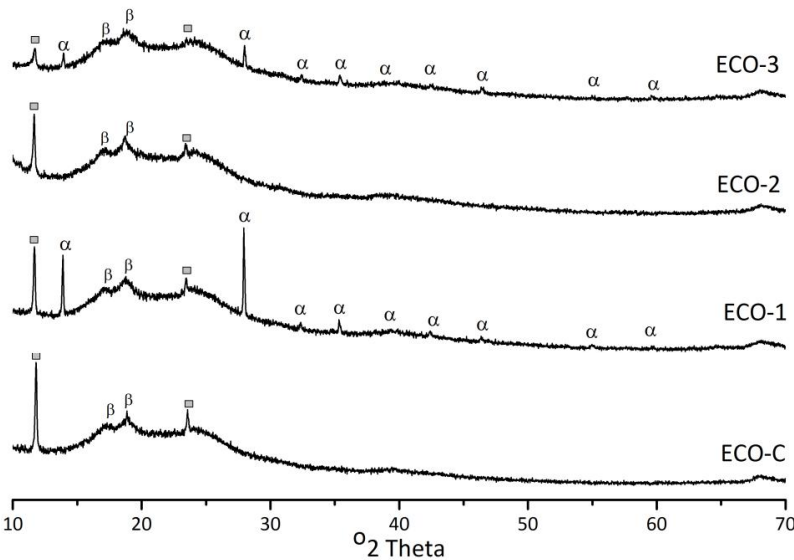

Fig. 3. X-ray diffraction of ECO series of Ag and As doped polymers 
For each of the samples tested, ion release profiles were determined, specifically analyzing $\mathrm{Ag}$ and As release after 30 days incubation in deionized (DI) water. Each of the control materials, PLA-C, HEX-C and ECO-C did not exhibit any Ag or As release - as expected; the data are presented in Table 2. The HEX-1, PLA-1 and ECO-1 samples showed As release of 14,9 and $19 \mathrm{mg} / \mathrm{L}$, respectively. HEX-2, PLA-2 and ECO-2 each had very low $\mathrm{Ag}$ release rates $<1 \mathrm{mg} / \mathrm{L}$. We recall that HEX-3, PLA-3 and ECO-3 samples contained both As and Ag. For each sample Ag was found to be $<1 \mathrm{mg} / \mathrm{L}$, while the As levels were 12,11 and $21 \mathrm{mg} / \mathrm{L}$, respectively.

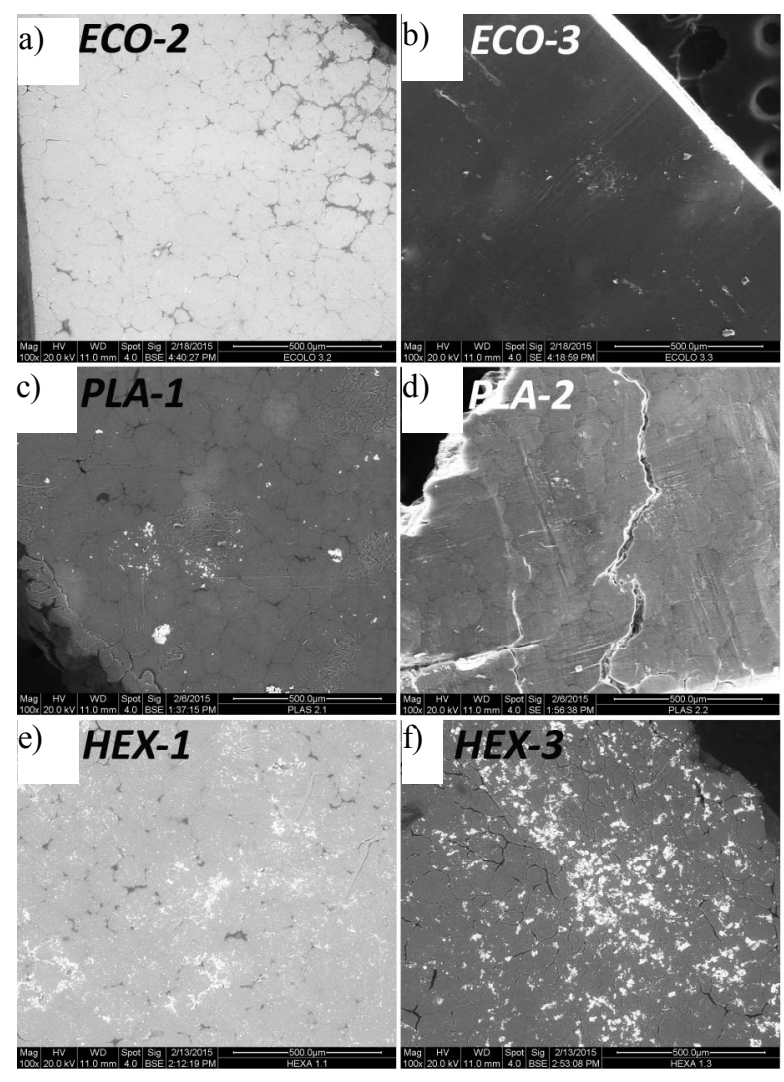

Fig. 4. SEM images of select sample surfaces from $\operatorname{ECO}(a, b), \operatorname{PLA}(c, d)$ and $\operatorname{HEX}(e, f)$
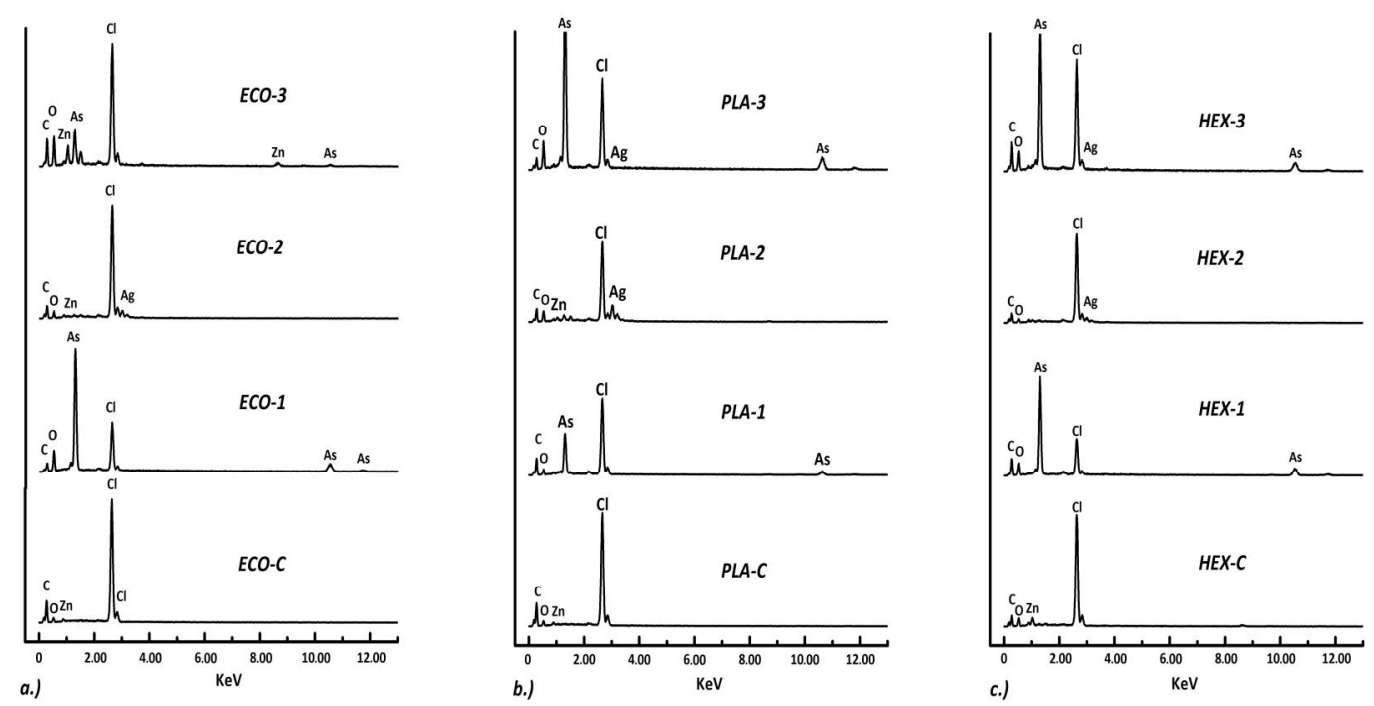

Fig. 5. EDX spectra of ECO (a), PLA (b) and HEX (c) 


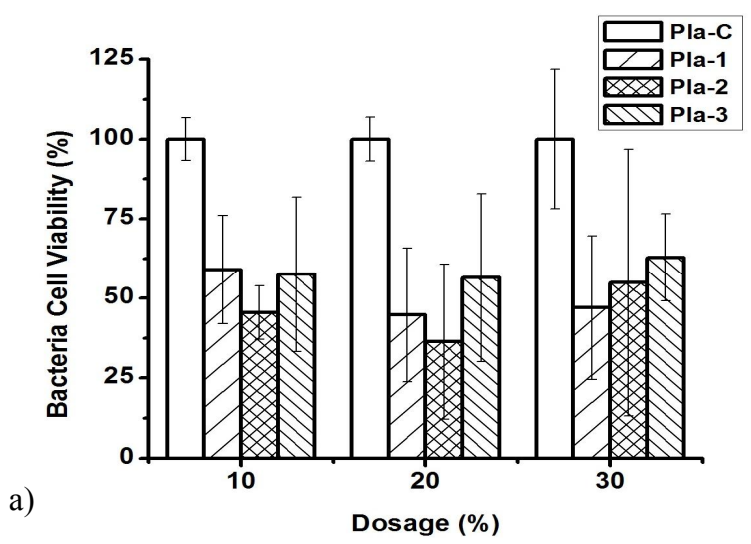

Fig. 6. Antibacterial evaluation

of liquid extracts in S. aureus at 10, 20 and 30\% dosage with respect to PLA (a), HEX (b) and ECO (c)

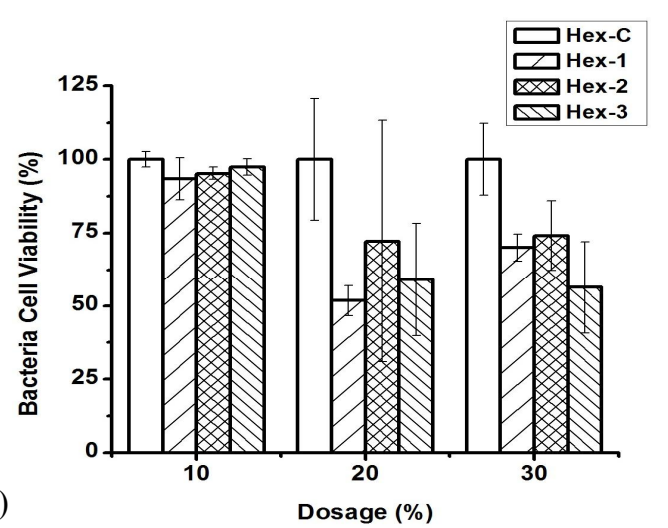

Fig. 6.

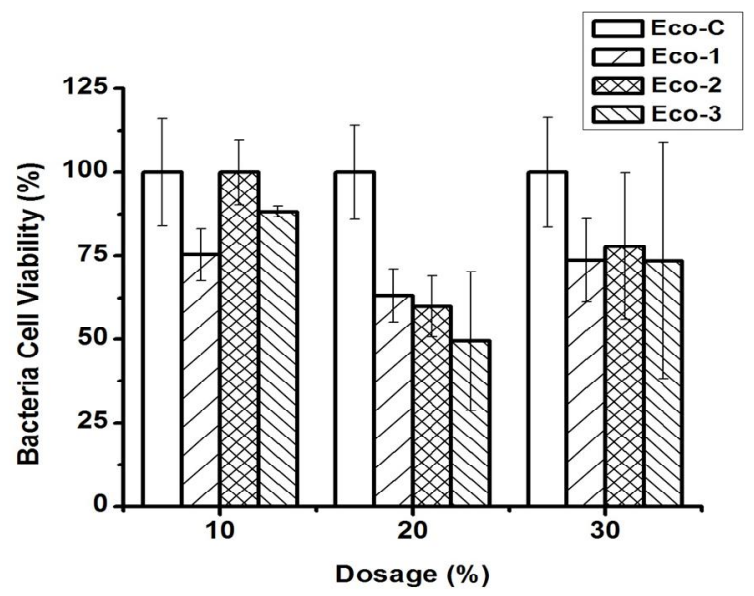

and coworkers ${ }^{16}$ have obtained Ag nanoparticles by a simple and eco-friendly atmospheric pressure plasma method, also using a capping agent. Effects of that agent concentration on the formation efficiency of the $\mathrm{Ag}$ nanoparticles, their average size and stability have been studied. Significant antibacterial activity on two strains of Gram bacteria has been found.

Since humans wear clothes, anti-bacterial properties of textiles are pertinent. Matyjas-Zgondek and coworkers ${ }^{17}$ have studied bacteriostatic efficacy of selected silver particles in the finishing of textiles: nano-Ag, sub-micro-Ag and $\mathrm{AgCl}$. Two strains of bacteria: Gram-positive (Bacillus subtilis) and Gram-negative (Escherichia coli) were studied. Mostly silver compounds were well dispersed on the fabric surface, but in some cases those compounds form agglomerates of single particles. The authors conclude that the antibacterial treatment of textile fabrics "can easily be achieved".

Table 2. Ion release profiles of HEX, PLA and ECO samples, specifically Ag and As release (mg/L)

\begin{tabular}{|c|c|c|c|c|c|c|c|c|}
\hline & Ag & As & & Ag & As & & Ag & As \\
\hline HEX-C & - & - & PLA-C & - & - & ECO-C & - & - \\
\hline HEX-1 & - & $13.6(2.3)$ & PLA-1 & - & $8.6(1.0)$ & ECO-1 & - & $19.3(2.0)$ \\
\hline HEX-2 & $<1.0$ & - & PLA-2 & $<1.0$ & - & ECO-2 & $<1.0$ & - \\
\hline HEX-3 & $<1.0$ & $12.2(2.0)$ & PLA-3 & $<1.0$ & $11.2(1.0)$ & ECO-3 & $<1.0$ & $21.5(1.9)$ \\
\hline
\end{tabular}




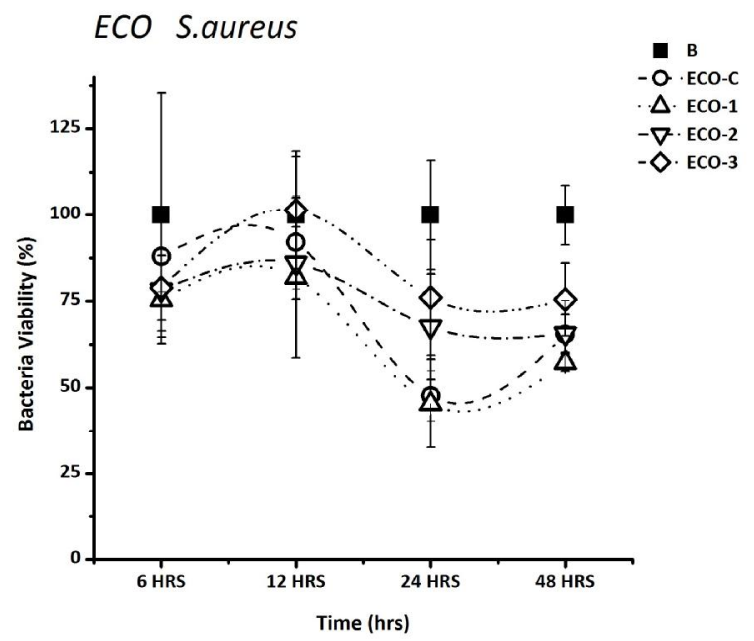

Fig. 7. ECO series tested in S. aureus over 6, 12, 24 and $48 \mathrm{~h}$ of incubation

PLA S.aureus

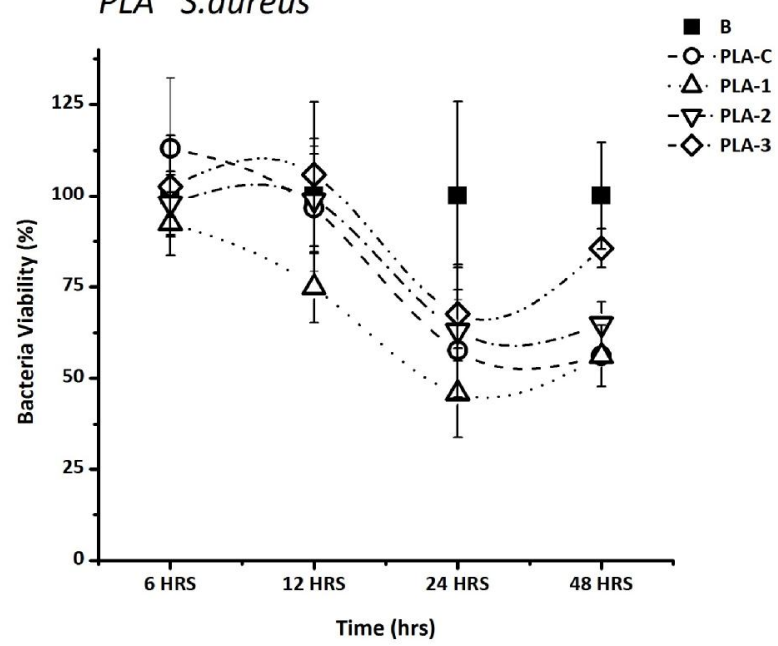

Indirect prevention of bacterial activity also deserves to be noted. Ravichand and coworkers in Hyderabad ${ }^{18}$ have developed a method of drinking water purification by creation of membranes. Poly(vinylidene fluoride) membranes were hydrophilized by blending with the polyvinyl alcohol and then cross-linking with glutaraldehyde.

Koval and Starchevskyy ${ }^{19}$ stress the fact that the water treatment technology has to exclude the use of chemical reagents such as chlorine or ozone - which lead to the formation of toxic compounds. As noted in a textbook of Materials Science and Engineering "the toxic effects on human health deserve more attention". Koval and Starchevskyy applied the acoustic cavitation via ultrasound in the presence of several gases bubbled through the aqueous media: $\mathrm{Ar}, \mathrm{He}, \mathrm{CO}_{2}$ and $\mathrm{O}_{2}$. They studied the viability of Diplococcus, Sarcina lutea,

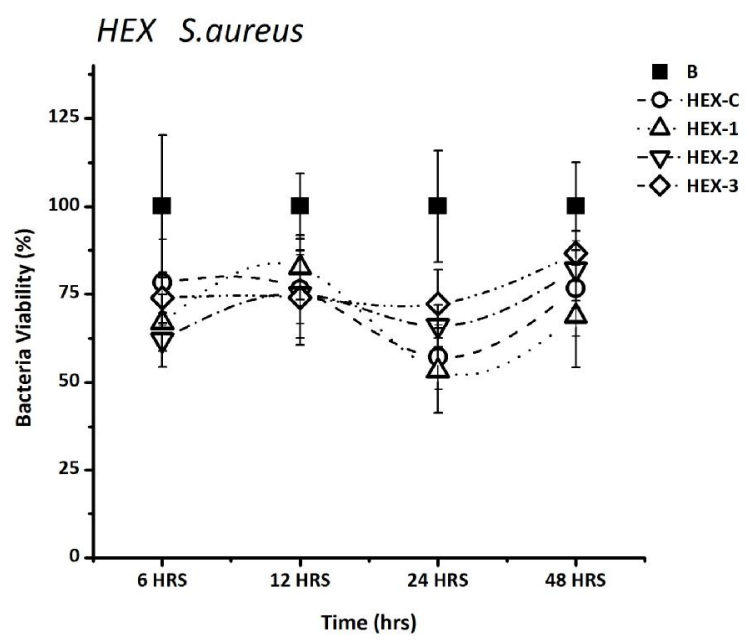

Fig. 8. HEX series tested in S. aureus over 6, 12, 24 and $48 \mathrm{~h}$ of incubation

Fig. 9. PLA series tested in S. aureus over 6, 12, 24 and $48 \mathrm{~h}$ of incubation
Bacillus cereus as well as Pseudomonas fluorescens bacteria and also the yeast (Saccharomyces cerevisiae) in natural water and in wastewater. The most efficient microorganism destruction has been obtained using the acoustic cavitation via ultrasound in the presence of bubbled Ar.

Consider now review articles written for use in teaching. There are articles on crystallography ${ }^{20}$, on viscoelasticity $^{21}$, on electronic materials systems for power transmission $^{22}$, on Materials Science learning experience at a university venue for middle school students ${ }^{23}$, on converting traditional Materials laboratories to projectbased learning experiences ${ }^{24}$, on "green" approach with an example of using post-consumer waste ${ }^{25}$, on polymers in the production of crude oil ${ }^{26-29}$. As noted by Gedde and Hedenqvist ${ }^{30}$, the same general laws are applied to both synthetic and natural polymers - while relations between 
mechanical and tribological properties of polymers exist ${ }^{31}$. Our results reported above seem also to suggest that antibacterial behavior of polymers deserves attention in the instruction as well.

\section{Conclusions}

Initially characterization of the materials was conducted to determine differences in the structure, morphology and solubility of the processed composites. HEX-C was found to contain no $\mathrm{Ag}_{2} \mathrm{O}$ or $\mathrm{As}_{2} \mathrm{O}_{3}$, while organic components of the polymer phase were evident: $\mathrm{C}_{12} \mathrm{H}_{7} \mathrm{NO}_{2}$ and $\mathrm{C}_{2} \mathrm{H}_{3} \mathrm{Cl}$. Amorphous humps are present within the $15-30^{\circ} 2$ theta range. HEX-1 and HEX-3 were found to contain crystalline peaks indicative of $\mathrm{As}_{2} \mathrm{O}_{3}$ while the incorporation of $\mathrm{Ag}_{2} \mathrm{O}$ did not induce any crystallinity in HEX-2 and HEX-3.

SEM and EDX analyses were used to further image the composite samples to verify processing consistency and determine the elemental composition. As is present in ECO- 1 and ECO-3 and Ag is present in ECO-2 but absent in ECO-3.

Antibacterial evaluation of each of the composite against $E$. coli, $S$. aureus, $C$. albicans and $S$. epidermidis was conducted. At $20 \%$ of each of the bacterial agents the bacterial cell viability was reduced significantly.

For each of the samples tested, ion release profiles were determined, specifically analyzing Ag and As release after 30 days incubation in DI water. Some of the compositions showed very low $\mathrm{Ag}$ release rates $<1 \mathrm{mg} / \mathrm{L}$.

\section{Acknowledgments}

One of us (M.G.) acknowledges gratefully a senior scholarship from the Fulbright Program, an international educational exchange program sponsored by the U.S. Government, Washington, DC, for a stay at the University of North Texas.

\section{References}

[1] Galya, T.; Sedlarik, V.; Kuritka, I.; Novotny, R.; Sedlarikova, J.; Sah, P. Antibacterial Poly(Vinyl Alcohol) Film Containing Silver Nanoparticles: Preparation and Characterization. J. Appl. Polym. Sci. 2008, 110 (5), 3178-3185. https://doi.org/10.1002/app.28908

[2] Robbens, J.; Vanparys, C.; Nobels, I.; Blust, R., Van Hoecke, K., Janssen, C., De Schamphelaere, K., Roland, K., Blanchard, G., Silvestre, F. et al. Eco-, Geno- and Human Toxicology of BioActive Nanoparticles for Biomedical Applications. Toxicology 2010, 269, 170-181. https://doi.org/10.1016/j.tox.2009.11.002 [3] Chandran, S.P.; Chaudhary, M.; Pasricha, R.; Ahmad, A.; Sastry, M. Synthesis of Gold Nanotriangles and Silver Nanoparticles Using Aloevera Plant Extract. Biotechnol. Prog. 2006, 22, 577-583. https://doi.org/10.1021/bp0501423
[4] Brostow, W.; Hagg Lobland, H.E.; Narkis, M. Sliding Wear, Viscoelasticity, and Brittleness of Polymers. J. Mater. Res. 2006, 21, 2422-2428. https://doi.org/10.1557/jmr.2006.0300

[5] Olea-Mejia, O.J.; Brostow, W.; Escobar-Halarcon, L.; ViguerasSantiago, E. Tribological Properties of Polymer Nanohybrids Containing Gold Nanoparticles Obtained by Laser Ablation. $J$. Nanosci. Nanotechnol. 2012, 12, 2750-2755(6).

https://doi.org/10.1166/jnn.2012.5737

[6] Brostow, W.; Hagg Lobland H.E. Materials: Introduction and Applications; John Wiley \& Sons: Hoboken, NJ, 2017.

[7] Brostow, W.; Gahutishvili, M.; Gigauri, R.; Hagg Lobland, H.E.; Japaridze, S.; Lekishvili, N. Separation of Natural Trivalent Oxides of Arsenic and Antimony. Chem. Eng. J. 2010, 159, 24-26.

https://doi.org/10.1016/j.cej.2010.02.016

[8] Barbakadze, K.; Brostow, W.; Datashvili, T.; Hnatchuk, N.; Lekishvili, N. Antibiocorrosive Epoxy-Based Coatings with Low Friction and High Scratch Resistance. Wear 2018, 394-395, 228235. https://doi.org/10.1016/j.wear.2017.08.006

[9] Gakhutishvili, M.; Gigauri, R. Extraction of Arsenic from Mineral Resources and Industrial Waste. Georgia Chem. J. 2010, 4 (10), 53-54.

[10] Bakradze, E., Vodyanitskii, Y., Urushadze, T., Chankseliani, Z., Arabidze, M., About rationing of the heavy metals in soils of Georgia, Ann. Agrarian Sci. 2018, 16, 1-6.

[11] Raffoux, E.; Rousselot, Ph., Poupon, Daniel , M.-T., Cassinat, B. , Delarue, R., Taksin, A.-L., Réa, D., , Buzyn, A. , Tibi, A. , Lebbé, G. et al., Combined Treatment With Arsenic Trioxide and All-Trans-Retinoic Acid in Patients With Relapsed Acute Promyelocytic Leukemia. J. Clin. Oncol. 2003, 21, 2326-2334. https://doi.org/10.1200/JCO.2003.01.149

[12] Soignet, S.L., Tong, W.P., Hirschfeld, S., Warrell Jr., R.P. Clinical Study of an Organic Arsenical, Melarsoprol in Patients with Advanced Leukemia. Cancer Chemother. Pharmacol. 1999, 44, 417-421.

[13] Baláž, P.; Sedlák, J. Arsenic in Cancer Treatment: Challenges for Application of Realgar Nanoparticles (A Minireview). Toxins 2010, 2(6), 1568-1581. https://doi.org/10.3390/toxins2061568 [14] Brostow, W.; Brumbley, S.; Gahutishvili, M.; Hnatchuk, N. Arsenic Antibacterial Polymer Composites Based on Poly(Vinyl Chloride). Macromol. Symp. 2016, 365, 258-262.

https://doi.org/10.1002/masy.201650002

[15] Skiba, M.; Pivovarov, A.; Vorobyova, V. The Plasma-Induced Formation of PVP-Coated Silver Nanoparticles and Usage in Water Purification. Chem. Chem. Technol. 2020, 14, 47-54.

https://doi.org/10.23939/chcht14.01.047

[16] Skiba, M.; Vorobyova, V.; Kovalenko, I.; Shakun, A. Synthesis of Tween-Coated Silver Nanoparticles by a Plasma-Chemical Method: Catalytic and Antimicrobial Activities. Chem. Chem. Technol. 2020, 14, 297-303.

https://doi.org/10.23939/chcht14.03.297

[17] Matyjas-Zgondek, E.; Bacciarelli, A.; Rybicki, E.;

Szynkowska, M.I.; Kołodziejczyk, M., Antibacterial Properties of

Silver-Finished Textiles, Fibres Text. East. Eur. 2008, 5, 101-107.

[18] Kancharla, R.; Vadeghar Ramesh, K.; Prabhakar Ginuga, R.;

Sundergopal, S. Synthesis and Characterization of Indigenous

Hydrophilized Polyvinylidene Fluoride Membrane for Drinking

Water Purification: Experimental Study and Modeling Aspects.

Chem. Chem. Technol. 2020, 14, 239-250.

https://doi.org/10.23939/chcht14.02.239

[19] Koval, I.; Starchevskyy, V. Gas Nature Effect on the

Destruction of Various Microorganisms Under Cavitation Action. 
Chem. Chem. Technol. 2020, 14, 264-270.

https://doi.org/10.23939/chcht14.02.264

[20] Moeck, P.; Stone-Sundberg, J.; Snyder, T.J.; Kaminsky, W. Enlivening 300 Level General Education Classes on Nano-Science and Nano-Technology with 3D Printed Crystallographic Models. $J$. Mater. Educ. 2014, 36, 77-96.

[21] Acevedo, A.; Herrera-Posada, S. Introducing Viscoelasticity to Precollege Students through a Composite Bouncing Balls Hands-On Experiment. J. Mater. Educ. 2014, 36, 69-76.

[22] López-Martinez, A.; Mata-Jiménez, M.; Andrade, M; AlanizLumbreraz, D.; Torres-Arguelles, V.; Olvera-González, E.; de la RosaMiranda, E.; Castaño, V.M. Non-Linear Voltage Control in Complex Electronic Materials Systems for Power Transmission:

- A Teaching Approach. J. Mater. Educ. 2014, 36, 97-105.

[23] Steinberg, D.; Swilley, S. Creating Positive Materials Science Learning Experiences at a University Venue for 1000 Middle School Students. J. Mater. Educ. 2008, 30, 351-360.

[24] Vanasupa, L.; Chen, K.C.; Stolk, J.; Savage, R.; Harding, T.; London, B.; Hughes, W. Converting Traditional Materials Labs to Project-Based Learning Experiences: Aiding Students' Development of Higher-Order Cognitive Skills. J. Mater. Educ. 2008, 30, 281286.

[25] Boice, J.N.; King, C.M.; Higginbotham, C.; Guerney, R.W. Molecular Recycling: Application of the Twelve Principles of Green Chemistry in the Diversion of Post-Consumer Poly(Lactic Acid) Waste. J. Mater. Educ. 2008, 30, 257-280.

[26] Spinelli, L.S., Lucas, E.F. Polymers in the Production of Crude Oil: I. Experimental Discipline to Teach Laboratory Tests to Evaluate Polymers Performance. J. Mater. Educ. 2017, 39, 125-130. [27] Vianna, E.L.F., Figueiredo, V.V., Middea, A., Brandão, V.S., Bertolino, L.C., Spinelli, L.S. Polymers in the Production of Crude Oil: II: An Experimental Procedure to Prepare Polymeric Magnetic Nanocomposites. J. Mater. Educ. 2019, 41(1-2), 41-50.

[28] Carvalho, S.P., Palermo, L.C.M., Boak, L.S., Sorbie, K.S., Lucas, E.F. Polymers in the Production of Crude Oil: III: Static Compatibility and Adsorption Test Procedure for Scale Inhibition. $J$. Mater. Educ. 2019, 41(3-4), 95-102.

[29] Silva, J. da C., Maravilha, T.S.L., Nunes, R. de C.P., Spinelli, L.S., Lucas, E.F. Polymers in the Production of Crude Oil: IV.
Extractiopn of Asphaltenes Fraction Using Soxhlet. J. Mater. Educ. 2019, 41(5-6), 149-156.

[30] Gedde, U.W., Hedenqvist, M.S. Fundamental Polymer Science, $2^{\text {nd }}$ ed.; Springer Nature Switzerland AG, 2019.

https://doi.org/10.1007/978-3-030-29794-7

[31] Brostow, W., Fałtynowicz, H., Gencel, O., Grigoriev, A., Hagg Lobland, H.E., Zhang, D. Mechanical and Tribological Properties of Polymers and Polymer-Based Composites. Chem. Chem. Technol. 2020, 14, 514-520. https://doi.org/10.23939/chcht14.04.514

Received: May 09, 2021 / Revised: May 24, 2021 / Accepted: July 12, 2021

\section{АНТИБАКТЕРІАЛЬНА ЕФЕКТИВНІСТЬ ПОЛІМЕРНИХ КОМПОЗИТІВ, ЛЕГОВАНИХ СРІБЛОМ АБО МИШ'ЯКОМ ПРОТИ КІЛЬКОХ ВИДІВ БАКТЕРІЙ}

Анотація. Досліджено структуру та ряд властивостей полімерних композитів, легованих $\mathrm{AgNO}_{3} \mathrm{ma} \mathrm{As}_{2} \mathrm{O}_{3}$, зокрема їхню антибактеріальну активність щодо E. coli, $S$. aureus, C. albicans ma S. еріdermidis. Нові полімерні композити, леговані сріблом або мим'яком, охарактеризовані за допомогою дифракиії рентгенівських променів (XRD), скануючоі електронної мікроскопії в поєднанні з енергодисперсійною рентгенівською спектроскопією (SEM/EDS) та дослідженнями вивільнення йонів. Проведено антибактеріальну оиінку кожного з композиційних зразків з використанням S. aureus y рідкій бульйонній культурі з додаванням до бактеріальної культури 10, 20 та $30 \%$ рідкого екстракту. Контрольні зразки $S$. aureus використовували для порівняння і реєстрували при $100 \%$ в кожен період часу. Встановлено, щчо для зразків із пластифікатором PLA життєздатність бактерій значно знижується для кожної композииї, щзо містить $\mathrm{Ag} / \mathrm{As}$, $\mathrm{i} \epsilon$ подібною до кожної дози концентрації.

Ключові слова: миш'якові композити, срібні композити, полімерні композити, антибактеріальна поведінка. 